\title{
A comprehensive study on performance-based budgeting model: A case study of Iran's policy
} making, implementing and monitoring

\author{
Ghodratollah Talebnia ${ }^{\mathrm{a}}$, Hamid Reza Vakilifard ${ }^{\mathrm{a}}$, Yahya Hassas Yeganeh ${ }^{\mathrm{b}}$ and Rahmatollah \\ Mohammadipour $^{\mathrm{c}^{*}}$
}

${ }^{a}$ Faculty Members of Department of Accounting, Science and Research Branch, Islamic Azad University. Tehran, Iran

${ }^{b}$ Faculty member of Allameh Tabatabai University,Tehran,Iran

${ }^{c}$ PhD student, Department of Accounting, Science and Research Branch, Islamic Azad University. Tehran, Iran

\begin{tabular}{|c|c|}
\hline A R T I C L E I N F O & A B S T R A C T \\
\hline $\begin{array}{l}\text { Article history: } \\
\text { Received April 19, } 2012 \\
\text { Accepted 12 June } 2012 \\
\text { Available online } \\
\text { June } 142012 \\
\text { Keywords: } \\
\text { Performance-based } \\
\text { budgeting(PBB) } \\
\text { Iran } \\
\text { Policy making } \\
\text { Monitoring } \\
\text { Implementing }\end{array}$ & $\begin{array}{l}\text { Performance-based budgeting (PBB) is the latest attempt to use performance indicators in } \\
\text { allocation of resources in public sector. PBB experts normally attempt to place emphasis on } \\
\text { output and outcome instead of input. Iran has made efforts to establish the PBB system but so } \\
\text { far this goal has not been realized. The methodology of the research is descriptive by the means } \\
\text { of survey-analytical approach. In the research, the possibility of establishment of PBB in Iran is } \\
\text { examined from three perspectives (Policymaking, Implementing, and Monitoring). The } \\
\text { conceptual model of this research is formed with a comprehensive review of literature of PBB } \\
\text { all over the world. At first, with an extensive review of literature in the countries who } \\
\text { implemented PBB or trying to implement it, we identify all variables, which are necessary for a } \\
\text { suitable Performance Budgeting model. Then the PBB experts test the necessity of these } \\
\text { variables in Iran and finally the existence has been proved by the statistical methods with the } \\
\text { Iranian model. }\end{array}$ \\
\hline
\end{tabular}

\section{Introduction}

The traditional line-item budgeting embodies several impediments for promoting efficient public planning and management as well as fostering result-oriented accountability in public sector institutions. Line-item budget focuses inputs and provides necessary data on how much is spent and how it is spent rather than what it is spent for. It does not build a linkage between inputs with outputs and hence does not say much on how efficiently resources are implemented. The line item budget tends to concentrate on decision making on details - whether the general office costs such as pencils used, printing paper consumed, etc. are appropriate and how much they have gone up or down compared with last year's budget - rather than on the efficiency and effectiveness of the program. 
The focus on detailed line-item control leads to micromanagement of agency operations by central budget offices and finance ministries and hierarchical controls within the agency.

Public managers have very limited managerial discretion and they are held responsible for the performance of government's activities. On the other hand, PBB depends on performance information concerning the achievement of intended organizational or program results. Ideally, decision makers will utilize performance information as a criterion in resource allocation to give incentives or punishments so that better results may be achieved.

According to $\mathrm{PBB}$, the budget is the tool that rewards or punishes agencies and programs based on their performance achievements. One important reason for adopting PBB is the promise that the practice holds to determine whether programs work and thus deserve budget increase.

The past two decades have witnessed a growing interest for performance management and budgeting reforms since there was a bigger public demands for government accountability in industrial countries. The primary objective of these reforms is to transform public budgeting systems from inputs control to an output and/or outcome focus in the interest of improving operational efficiency and promoting result-oriented accountability. These experiences have significant relevance to public sector reforms in developing countries. Iran is one of the countries that have tried to establish PBB but this goal has not been achieved yet. In this study, to recognize the main factors of implementing PBB in Iran, we have studied the history of PBB in many countries to know how they were capable of accomplishing PBB and determine important factors, which are necessary to implementation PBB in Iran. Then, we asked the budgeting experts to help verify those factors. To do that, we used a questionnaire based on the Likert scale consisting of 23 questions.

\section{Theoretical framework of research}

In recent years, budget decision-makers and the general public have demanded better accountability for not just the use of resources, but for results that public programs generate. As a result, the principles of PBB have gained popularity. PBB attempts to deliver market-like information to the public sector. It sends results to budget decision makers in the same way profits send investment indicators to financiers in the private sector. PBB injects information on accomplishments into the resource allocation process.

PBB refers generally to the process of linking expected results to budget levels but not to any particular approach. Thus, there is no definitive PBB process yet; both the concept and techniques of PBB have evolved considerably since 1950. In the US for the time it was from the Hoover Commission in 1949 (Mc.Gill, 2001). The second was the planning-programming-budgeting-system (PPBS), championed by President Johnson in 1965. The third was management by objectives (MBO) initiated in 1973 by President Nixon. The last was zero-base budgeting (ZBB) championed by President Carter. All have led to the latest thrust; the Government Performance and Results Act (GPRA). Each of these initiatives established unique procedures for linking resources with results. A few countries, such as Australia, the Netherlands, New Zealand and the United Kingdom, have changed their budget structures to focus on results.

Others, such as Canada and the United States, have preferred to keep the existing budget structure and to add performance information in supplementary documents provided to the legislature. Many countries have altered their budget structures, however, many have struggled to integrate performance and financial information into the process. The Swedish government changed the structure of its budget to reflect government policy priorities in the mid-1990s, more precisely but there is still a clear separation between the financial and performance aspects. Governments have also tried to include performance information in budget negotiations between the finance ministry and spending ministries, and in negotiations between spending ministries and agencies. Following parts of the 
article show the history of $\mathrm{PBB}$ around the world and help to recognize the main variables of implementing PBB.

\subsection{Australia}

The nature of performance information in Australia's financial management framework may have changed, but the necessary objectives remain very much the same. They are to improve both the costeffectiveness of resource used and public accountability while devolving financial management responsibility and flexibility to those who deliver policies and programs. The approach adapted by Australia to incorporate a focus on performance is a long-term, iterative process. This has provided many benefits in addition to the opportunity to learn from experience before proceeding with further reforms. This is an important issue because of the interrelationship between performance and other aspects of the financial, accountability, political and management environment. The complexity of interactions and incentives is difficult to comprehend in isolation from practical experience, making "big bang" changes potentially high risk (Havke, 2007; Blöndal \& Bergvall, 2007). Australia has faced two recurring themes in establishing good performance information:

- The quality of performance information in relation to agency contributions

to outcomes and outputs;

- The limited use of the performance information for decision making in the budget context. Outcomes and outputs will remain essential parts of Australia's budgeting and management framework. However, it is important to ensure that links between programs, outputs and outcomes are clear and are measured effectively, particularly if this performance information is to be relied on for budget decision making.

\subsection{New Zealand}

New Zealand's public management reforms were designed to move the focus from what resources were being used, to what was being produced and what outcomes were achieved as a result. Considerable gains have been made, particularly in understanding what is being produced and how much it costs. Further work is underway to develop outcome management systems. There are also significant efforts applied to move outcomes into the core of the practice of public management in New Zealand. One of the lessons, which could be learnt from the New Zealand experience, is that creating an environment that enables outcomes-focused management is unlikely to be sufficient. It is difficult to define measure and manage for outcomes, and in some areas of government activities, it is probably be relatively difficult. Central agencies must balance the requirements to be responsive to the constraints that specific agencies face, with the need to provide impetus and leadership from the centre. It is important to focus on outcomes in both the formal and informal parts of the public management system. A third lesson that can be drawn from the New Zealand experience is that moving the focus to outcomes forces government to rethink its attitude to risk (Warren \& Barnes, 2002).

\subsection{Denmark}

Lessons learned from the performance contracts in the early 1990s have provided valuable input to the recent adjustment of the performance management system. One lesson was that the performance contracts had too many targets and objectives, most of which could not be measured. Furthermore, almost all the targets were related to the internal business of the organization: IT system development, work processes, competence development, etc. This meant that the agencies were not sufficiently oriented towards the needs they were supposed to be serving - that is, the needs of citizens and private companies (Blöndal \& Ruffner, 2004). 


\subsection{Poland}

Milestones of PBB implementation in Poland 2008 (Hawkesworth et al., 2011):

$>$ Analysis of legal acts for the purpose of performance budget implementation

$>$ Elaboration of methodological foundations for multi-annual performance planning

$>$ Preparation of assumptions for legal acts regulating the functioning of the performance budget, including multi-annual performance planning

$>$ Preparation of projects co-financed from EU funds, aimed at implementation of the performance budget 2009

$>$ Elaboration of performance budget methodology

$>$ Elaboration of guidelines for preparing a report on execution of the budget in performance Form

$>$ Elaboration of assumptions for an it system for servicing the performance budget 2010

$>$ Elaboration of a concept of monitoring the execution of the budget in performance form

$>$ Completion of a first stage of works on the performance budget reporting system, enabling the monitoring of public expenditures 2011

$>$ Completion of works on an indicators database for functions of the state

$>$ Completion of the second stage of works on a performance budget reporting system, enabling the monitoring of public expenditures

$>$ Conducting the first monitoring and reporting on performance budget execution 2012

$>$ Preparing the first parallel draft budget act (traditional budget and PBB) for the 2013 budget year

$>$ Implementation of the methodology for effective public finance management at the central level by means of multi-annual performance planning and completed database of indicators 2014

$>$ Preparation of the report on the execution of the budget act comprising the execution of the performance budget in 2013 (in parallel to the traditional budget)

$>$ Elaboration of a report on the ex post evaluation of the execution of the 2013 budget act, as an instrument supporting the preparation of the $2014 \mathrm{draft}$ budget act 2015

$>$ Elaboration of a report concerning the impact of performance budget functioning on public finance

$>$ Financial settlement of the projects co-financed from the European Social Fund. In Iran the present budgeting isn't suitable and it's important to implement the PBB to add Economy, Efficiency and Effectiveness to the budgeting system and consumption of resources. Because of this, since 2001 until now the parliament has tried to provide basic rules and condition for establishing the PBB.

\section{Research method}

In this section, we present details of our proposed model. Fig. 1 demonstrates the framework of the proposed study. The framework of this study is shown in Table1. In fact, the first step is to recognize the main variables of implementing PBB in other countries. Then, for the second step we asked the of PBB experts in Iran to select the suitable variables for PBB by means of questionnaire. Statistical population of this research comprised $\mathrm{PhD}$ students of accounting, experts of budgeting in auditing organization, experts of budgeting in ministry of finance, financial managers in governmental organizations in Iran, auditors, etc. The sample consists of 136 individuals selected using following formula:

$$
n=\frac{z_{\alpha}^{2} / 2 \times p(1-p)}{\varepsilon^{2}}=\frac{1.96^{2} \times 0.5 \times 0.5}{0.085^{2}} \cong 136
$$


The validity of the instrument was obtained via experts ideas and its reliability was measured utilizing Cronbach's (0.88).

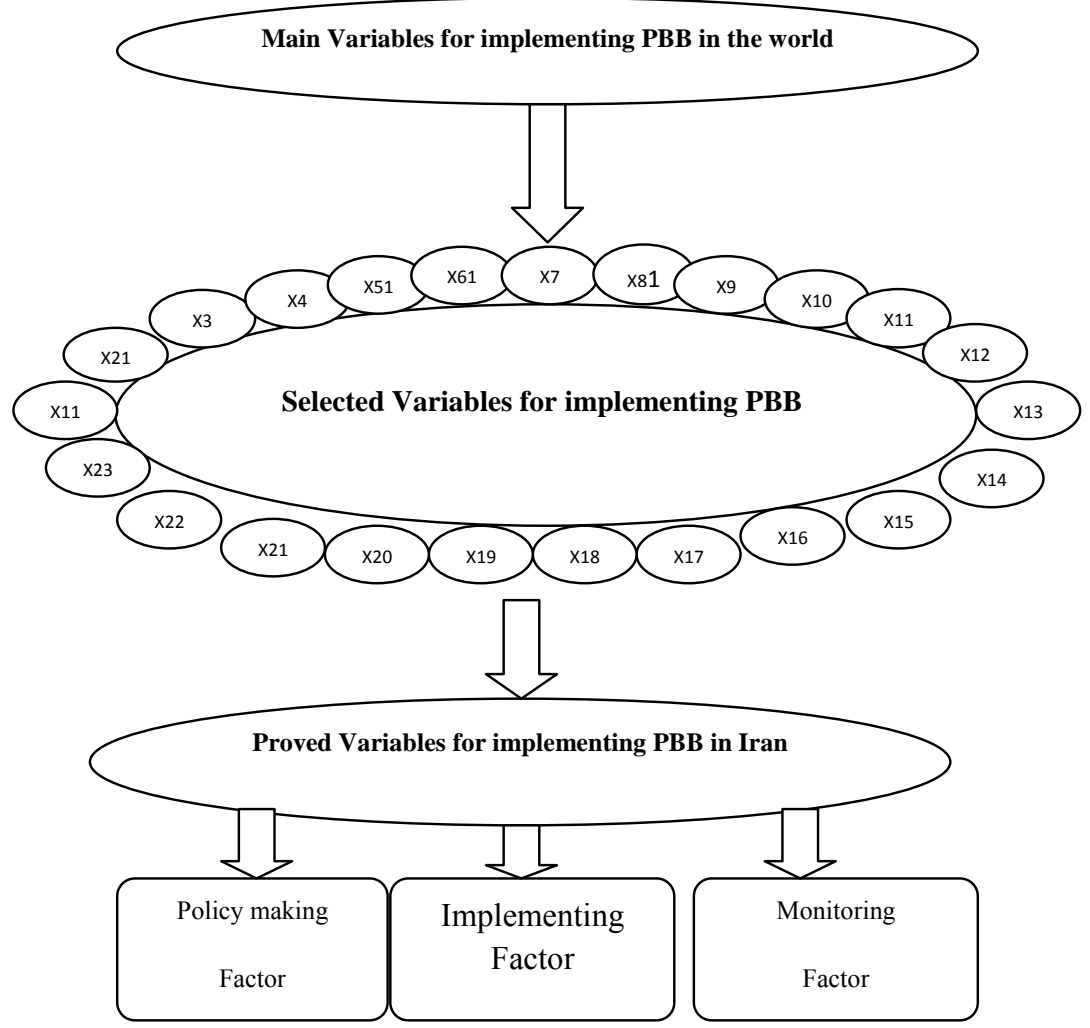

Fig. 1. The framework of the proposed model $\left(X_{1}\right.$ to $\left.X_{23}\right)$

\subsection{Questions of study}

Which factors are necessary for implementation of PBB in Iran?

What are the policymaking variables for implementation of PBB in Iran?

What are the implementing variables for implementation of PBB in Iran?

What are the monitoring variables for implementation of PBB in Iran?

Based on investigation of PBB's implementation necessary variables, following variables were derived:

$X_{1}$.Considering the Iran's twenty-year mission (2025)

$X_{2}$.Considering the law of economic, social and cultural development (every 5 years)

$X_{3}$.Considering the law of privatization (44th principal of constitution in Iran)

$X_{4}$. Reforming annual budget law (based on PBB)

$X_{5}$.Reforming public audit law (in government)

$X_{6}$. Reforming country services management law

$X_{7}$.Creating an independent organization for advice other agencies and organizations in related to determination of outputs, outcomes and performance indexes

$X_{8}$.Creating governmental accounting standards in Iran $X_{9}$.Implementing Accrual accounting in public segment

$X_{10}$.Creating comprehensive management and accounting databases in agenesis

$X_{11}$. Reducing reliance on foreign loans by government
$X_{13}$.Training specialists in PBB field

$X_{14}$.Implementing the activity Based Costing

$X_{15}$.Appropriating reward and punishment system

$X_{16}$.Granting authority to managers to develop processes and administrative reform, fiscal and employment

$X_{17}$. Choosing one or more organizations as pilot before implementing PBB in all organizations

$X_{18}$.Quantifying Strategic plans accurately and implement them with precision in a current conditions and needs of citizens

$X_{19}$.Implementing Performance Auditing in public section

$X_{20}$.Considering financial and non-financial performance information for assessing

$X_{21}$.Considering performance information as main basis in allocating resources

$X_{22}$.Controlling the Progress of projects in public sector

$X_{23}$. Rewarding managers based on their performance 
$X_{12}$. Strengthening culture of accountability in organizations and society

We test each variable based on binomial test using the following hypotheses test,

$\begin{cases}H_{0}: & p \leq 0.6 \\ H_{1}: & p>0.6\end{cases}$

As Table 1 shows, all variables were significant in level of 0.05 , which proves the hypotheses. To classify the variables, we applied Factor Analysis which is a usual statistical method for identification of basic factors. Factor analysis has four steps:

1-Making matrix of correlation coefficients

2-Derivation of factors from correlation matrix

3-Rotation of factors to maximize the relationship between variables and factors

4-Calculating the weight of factors

Table 1

The results of testing 23 hypotheses using binomial test

\begin{tabular}{|c|c|c|c|c|c|c|c|c|c|c|c|c|c|}
\hline & & Category & $\mathrm{N}$ & $\begin{array}{l}\text { Observed } \\
\text { Prop. }\end{array}$ & $\begin{array}{l}\text { Test } \\
\text { Prop. }\end{array}$ & $\begin{array}{l}\text { Asymp. } \\
\text { Sig. (1- } \\
\text { tailed) }\end{array}$ & & & Category & $\mathrm{N}$ & $\begin{array}{l}\text { Observed } \\
\text { Prop. }\end{array}$ & $\begin{array}{l}\text { Test } \\
\text { Prop. }\end{array}$ & $\begin{array}{l}\text { Asymp. } \\
\text { Sig. (1- } \\
\text { tailed) }\end{array}$ \\
\hline \multirow{3}{*}{$\mathrm{x} 1$} & Group 1 & $<=3$ & 45 & .3 & .6 & $.000^{\mathrm{a}, \mathrm{b}}$ & \multirow{3}{*}{ x13 } & Group 1 & $<=3$ & 61 & .4 & .6 & $.000^{\mathrm{a}, \mathrm{b}}$ \\
\hline & Group 2 & $>3$ & 91 & .7 & & & & Group 2 & $>3$ & 75 & .6 & & \\
\hline & Total & & 136 & 1.0 & & & & Total & & 136 & 1.0 & & \\
\hline \multirow{3}{*}{$\mathrm{x} 2$} & Group 1 & $<=3$ & 53 & .4 & .6 & $.000^{\mathrm{a}, \mathrm{b}}$ & \multirow{3}{*}{$\mathrm{x} 14$} & Group 1 & $<=3$ & 61 & .4 & .6 & $.000^{\mathrm{a}, \mathrm{b}}$ \\
\hline & Group 2 & $>3$ & 83 & .6 & & & & Group 2 & $>3$ & 75 & .6 & & \\
\hline & Total & & 136 & 1.0 & & & & Total & & 136 & 1.0 & & \\
\hline \multirow{3}{*}{$\mathrm{x} 3$} & Group 1 & $<=3$ & 69 & .5 & .6 & $.018^{\mathrm{a}, \mathrm{b}}$ & \multirow{3}{*}{$\mathrm{x} 15$} & Group 1 & $<=3$ & 53 & .4 & .6 & $.000^{\mathrm{a}, \mathrm{b}}$ \\
\hline & Group 2 & $>3$ & 67 & .5 & & & & Group 2 & $>3$ & 83 & .6 & & \\
\hline & Total & & 136 & 1.0 & & & & Total & & 136 & 1.0 & & \\
\hline \multirow{3}{*}{$\mathrm{x} 4$} & Group 1 & $<=3$ & 120 & .9 & .6 & $.000^{\mathrm{b}}$ & \multirow{3}{*}{ x16 } & Group 1 & $<=3$ & 136 & 1.0 & .6 & $.000^{\mathrm{b}}$ \\
\hline & Group 2 & $>3$ & 16 & .1 & & & & Total & & 136 & 1.0 & & \\
\hline & Total & & 136 & 1.0 & & & & $\overline{\text { Group } 1}$ & $<=3$ & 45 & .3 & .6 & $.000^{\mathrm{a}, \mathrm{b}}$ \\
\hline \multirow{3}{*}{ x5 } & Group 1 & $<=3$ & 45 & .3 & .6 & $.000^{a, b}$ & \multirow{2}{*}{$x 17$} & Group 2 & $>3$ & 91 & .7 & & \\
\hline & Group 2 & $>3$ & 91 & .7 & & & & Total & & 136 & 1.0 & & \\
\hline & Total & & 136 & 1.0 & & & \multirow{2}{*}{$-x 18$} & Group 1 & $<=3$ & 136 & 1.0 & .6 & $.000^{\mathrm{b}}$ \\
\hline \multirow{4}{*}{ x6 } & Group 1 & $<=3$ & 53 & .4 & .6 & $.000^{a, b}$ & & Total & & 136 & 1.0 & & \\
\hline & Group 2 & $>3$ & 83 & .6 & & & \multirow{3}{*}{$\times 19$} & Group 1 & $<=3$ & 53 & .4 & .6 & $.000^{\mathrm{a}, \mathrm{b}}$ \\
\hline & Total & & 136 & 1.0 & & & & Group 2 & $>3$ & 83 & .6 & & \\
\hline & Group 1 & $<=3$ & 61 & .4 & .6 & $.000^{\mathrm{a}, \mathrm{b}}$ & & Total & & 136 & 1.0 & & \\
\hline \multirow[t]{3}{*}{$\mathrm{x} 7$} & Group 2 & $>3$ & 75 & .6 & & & \multirow{3}{*}{$\mathrm{x} 20$} & Group 1 & $<=3$ & 53 & .4 & .6 & $.000^{a, b}$ \\
\hline & Total & & 136 & 1.0 & & & & Group 2 & $>3$ & 83 & .6 & & \\
\hline & Group 1 & $<=3$ & 77 & .6 & .6 & $.006^{\mathrm{a}, \mathrm{b}}$ & & Total & & 136 & 1.0 & & \\
\hline \multirow{2}{*}{$\mathrm{x} 8$} & Group 2 & $>3$ & 59 & .4 & & & \multirow{2}{*}{$\mathrm{x} 21$} & Group 1 & $<=3$ & 136 & 1.0 & .6 & $.000^{\mathrm{b}}$ \\
\hline & Total & & 136 & 1.0 & & & & Total & & 136 & 1.0 & & \\
\hline \multirow{3}{*}{ x9 } & Group 1 & $<=3$ & 136 & 1.0 & .6 & $.000^{\mathrm{b}}$ & \multirow{3}{*}{ x22 } & Group 1 & $<=3$ & 53 & .4 & .6 & $.000^{\mathrm{a}, \mathrm{b}}$ \\
\hline & Total & & 136 & 1.0 & & & & Group 2 & $>3$ & 83 & .6 & & \\
\hline & Group 1 & $<=3$ & 53 & .4 & .6 & $.000^{\mathrm{a}, \mathrm{b}}$ & & Total & & 136 & 1.0 & & \\
\hline \multirow{2}{*}{$\mathrm{x} 10$} & Group 2 & $>3$ & 83 & .6 & & & \multirow{3}{*}{$\times 23$} & Group 1 & $<=3$ & 53 & .4 & .6 & $.000^{\mathrm{a}, \mathrm{b}}$ \\
\hline & Total & & 136 & 1.0 & & & & Group 2 & $>3$ & 83 & .6 & & \\
\hline \multirow{3}{*}{ x11 } & Group 1 & $<=3$ & 136 & 1.0 & .6 & $.000^{\mathrm{b}}$ & & Total & & 136 & 1.0 & & \\
\hline & Total & & 136 & 1.0 & & & & & & & & & \\
\hline & Group 1 & $<=3$ & 53 & .4 & .6 & $.000^{\mathrm{a}, \mathrm{b}}$ & & & & & & & \\
\hline \multirow{2}{*}{$\mathrm{x} 12$} & Group 2 & $>3$ & 83 & .6 & & & & & & & & & \\
\hline & Total & & 136 & 1.0 & & & & & & & & & \\
\hline
\end{tabular}


As the results of Factor Analysis shows, three Factors were recognized (see Table 2 and Table 3). These factors are introduced by the following relations:

$$
\begin{aligned}
F_{1}=0.795 \mathrm{X}_{1} & +.764 \mathrm{X}_{2}+.618 \mathrm{X}_{3}+.853 \mathrm{X}_{4}+.688 \mathrm{X}_{5}+.637 \mathrm{X}_{6}+.656 \mathrm{X}_{7}+.537 \mathrm{X}_{8}+.658 \mathrm{X}_{9} \\
& +.701 \mathrm{X}_{10}+.824 \mathrm{X}_{11}+.944 \mathrm{X}_{12}+.059 \mathrm{X}_{13}+.110 \mathrm{X}_{14}+.214 \mathrm{X}_{15}+.318 \mathrm{X}_{16} \\
& +.084 \mathrm{X}_{17}+.117 \mathrm{X}_{18}+.144 \mathrm{X}_{19}+.192 \mathrm{X}_{20}+.117 \mathrm{X}_{21}+.194 \mathrm{X}_{22}+.229 \mathrm{X}_{23} \\
F_{2}=.101 \mathrm{X}_{1}+ & .214 \mathrm{X}_{2}+.355 \mathrm{X}_{3}+.170 \mathrm{X}_{4}+.193 \mathrm{X}_{5}+.289 \mathrm{X}_{6}+.483 \mathrm{X}_{7}+.426 \mathrm{X}_{8}+.262 \mathrm{X}_{9} \\
& +.045 \mathrm{X}_{10}+.510 \mathrm{X}_{11}+.287 \mathrm{X}_{12}+.752 \mathrm{X}_{13}+.891 \mathrm{X}_{14}+.916 \mathrm{X}_{15}+.921 \mathrm{X}_{16} \\
& +.821 \mathrm{X}_{17}+.704 \mathrm{X}_{18}+.287 \mathrm{X}_{19}+.360 \mathrm{X}_{20}+.204 \mathrm{X}_{21}+.2874 \mathrm{X}_{22}+.360 \mathrm{X}_{23} \\
& \\
F_{3}=0.285 \mathrm{X}_{1} & +.163 \mathrm{X}_{2}+.042 \mathrm{X}_{3}+.135 \mathrm{X}_{4}+.151 \mathrm{X}_{5}+.353 \mathrm{X}_{6}+.258 \mathrm{X}_{7}+.280 \mathrm{X}_{8}+.501 \mathrm{X}_{9} \\
& +.079 \mathrm{X}_{10}+.226 \mathrm{X}_{11}+.060 \mathrm{X}_{12}+.165 \mathrm{X}_{13}+.085 \mathrm{X}_{14}+.304 \mathrm{X}_{15}+.096 \mathrm{X}_{16} \\
& +.046 \mathrm{X}_{17}+.096 \mathrm{X}_{18}+.860 \mathrm{X}_{19}+.933 \mathrm{X}_{20}+.964 \mathrm{X}_{21}+.660 \mathrm{X}_{22}+.733 \mathrm{X}_{23}
\end{aligned}
$$

\begin{tabular}{|c|c|c|c|c|c|c|c|c|c|}
\hline \multirow{2}{*}{ Component } & \multicolumn{3}{|c|}{ Initial Eigenvalues } & \multicolumn{3}{|c|}{ Extraction Sums of Squared Loadings } & \multicolumn{3}{|c|}{ Rotation Sums of Squared Loadings } \\
\hline & Total & $\%$ of Variance & Cumulative \% & Total & $\%$ of Variance & Cumulative $\%$ & Total & $\%$ of Variance & Cumulative $\%$ \\
\hline 1 & 17.139 & 74.517 & 74.517 & 17.139 & 74.517 & 74.517 & 11.547 & 50.203 & 50.203 \\
\hline 2 & 2.696 & 11.721 & 86.237 & 2.696 & 11.721 & 86.237 & 6.881 & 29.916 & 80.119 \\
\hline 3 & 1.658 & 7.207 & 93.444 & 1.658 & 7.207 & 93.444 & 3.065 & 13.325 & 93.444 \\
\hline 4 & .636 & 2.767 & 96.212 & & & & & & \\
\hline 5 & .534 & 2.321 & 98.532 & & & & & & \\
\hline 6 & .255 & 1.109 & 99.641 & & & & & & \\
\hline 7 & .083 & .359 & 100.000 & & & & & & \\
\hline 8 & $6.280 \mathrm{E}-15$ & $2.730 \mathrm{E}-14$ & 100.000 & & & & & & \\
\hline 9 & 3.687E-15 & $1.603 \mathrm{E}-14$ & 100.000 & & & & & & \\
\hline 10 & $3.375 \mathrm{E}-15$ & $1.467 \mathrm{E}-14$ & 100.000 & & & & & & \\
\hline 11 & $1.231 \mathrm{E}-15$ & $5.350 \mathrm{E}-15$ & 100.000 & & & & & & \\
\hline 12 & $9.454 \mathrm{E}-16$ & $4.111 \mathrm{E}-15$ & 100.000 & & & & & & \\
\hline 13 & $6.130 \mathrm{E}-16$ & $2.665 \mathrm{E}-15$ & 100.000 & & & & & & \\
\hline 14 & $2.316 \mathrm{E}-16$ & $1.007 \mathrm{E}-15$ & 100.000 & & & & & & \\
\hline 15 & $1.110 \mathrm{E}-16$ & $4.825 \mathrm{E}-16$ & 100.000 & & & & & & \\
\hline 16 & $1.620 \mathrm{E}-17$ & $7.045 \mathrm{E}-17$ & 100.000 & & & & & & \\
\hline 17 & $-2.432 \mathrm{E}-18$ & $-1.057 \mathrm{E}-17$ & 100.000 & & & & & & \\
\hline 18 & $-5.759 \mathrm{E}-16$ & $-2.504 \mathrm{E}-15$ & 100.000 & & & & & & \\
\hline 19 & $-1.154 \mathrm{E}-15$ & $-5.020 \mathrm{E}-15$ & 100.000 & & & & & & \\
\hline 20 & $-1.720 \mathrm{E}-15$ & $-7.477 \mathrm{E}-15$ & 100.000 & & & & & & \\
\hline 21 & $-2.274 \mathrm{E}-15$ & $-9.887 \mathrm{E}-15$ & 100.000 & & & & & & \\
\hline 22 & $-3.693 \mathrm{E}-15$ & $-1.606 \mathrm{E}-14$ & 100.000 & & & & & & \\
\hline 23 & $-4.744 \mathrm{E}-15$ & $-2.062 \mathrm{E}-14$ & 100.000 & & & & & & \\
\hline
\end{tabular}

Such that $X_{j}, j=1, \cdots, 23$ are variables and $F_{i}, 1=1,2,3$ are the factors.

Table 2

Total Variance Explained

Extraction Method: Principal Component Analysis.

To conduct a factor Analysis, we must make sure that the data are suitable for the analysis we use KMO Index and Bartlet Test to investigate the suitability of the data.

If the sig of Bartlet is less than 0.05 then using Factor Analysis would be suitable. In our study, the calculated KMO index is 0.86 , which shows that the size of sample is enough for Factor Analysis. Bartlet test findings demonstrate that at the statistical level of 0.05, the test is significant, which shows that Factor Analysis is a suitable tool for recognizing the structure of the model (see Table 4). 
Table 3

Component Matrix ${ }^{\mathrm{a}}$

\begin{tabular}{|c|c|c|c|}
\hline & \multicolumn{3}{|c|}{ Component } \\
\hline & 1 & 2 & 3 \\
\hline $\mathrm{x} 1$ & .979 & -.015 & .071 \\
\hline $\mathrm{x} 3$ & .923 & .053 & -.313 \\
\hline $\mathrm{x} 2$ & .989 & -.020 & -.098 \\
\hline $\mathrm{x} 5$ & .970 & .054 & -.178 \\
\hline $\mathrm{x} 4$ & .800 & -.311 & .195 \\
\hline $\mathrm{x} 6$ & .922 & .164 & .022 \\
\hline$x 7$ & .966 & .137 & -.103 \\
\hline $\mathrm{x} 8$ & .903 & .241 & -.144 \\
\hline $\mathrm{x} 9$ & .705 & .684 & -.032 \\
\hline $\mathrm{x} 10$ & .830 & -.118 & -.071 \\
\hline $\mathrm{x} 11$ & .748 & .475 & -.380 \\
\hline $\mathrm{x} 12$ & .919 & -.353 & .087 \\
\hline $\mathrm{x} 13$ & .934 & .146 & -.229 \\
\hline $\mathrm{x} 14$ & .934 & -.249 & .021 \\
\hline $\mathrm{x} 15$ & .878 & -.184 & .289 \\
\hline $\mathrm{x} 16$ & .693 & .417 & -.489 \\
\hline $\mathrm{x} 17$ & .850 & -.114 & .463 \\
\hline $\mathrm{x} 18$ & .448 & .666 & .583 \\
\hline x19 & .919 & -.353 & .087 \\
\hline $\mathrm{x} 20$ & .942 & -.326 & .016 \\
\hline $\mathrm{x} 21$ & .448 & .666 & .583 \\
\hline$x 22$ & .919 & -.353 & .087 \\
\hline$x 23$ & .942 & -.326 & .016 \\
\hline
\end{tabular}

Extraction Method: Principal Component Analysis.

a. 3 components extracted
Rotated Component Matrix

\begin{tabular}{|c|c|c|c|}
\hline & \multicolumn{3}{|c|}{ Component } \\
\hline & 1 & 2 & 3 \\
\hline $\mathrm{x} 1$ & .795 & .101 & .285 \\
\hline $\mathrm{x} 3$ & .618 & .355 & .042 \\
\hline $\mathrm{x} 2$ & .764 & .214 & .163 \\
\hline $\mathrm{x} 5$ & .688 & 693 & .151 \\
\hline $\mathrm{x} 4$ & .853 & .170 & .135 \\
\hline$x 6$ & .637 & .289 & .353 \\
\hline$x 7$ & .656 & .483 & .258 \\
\hline $\mathrm{x} 8$ & .537 & .726 & .280 \\
\hline $\mathrm{x} 9$ & .658 & .262 & .501 \\
\hline $\mathrm{x} 10$ & .701 & .458 & .079 \\
\hline $\mathrm{x} 11$ & .824 & .510 & .226 \\
\hline $\mathrm{x} 12$ & .944 & .287 & .060 \\
\hline $\mathrm{x} 13$ & .059 & .752 & .165 \\
\hline x14 & .110 & .891 & .085 \\
\hline $\mathrm{x} 15$ & .214 & .916 & .304 \\
\hline x16 & .318 & .921 & .096 \\
\hline $\mathrm{x} 17$ & .084 & .821 & .046 \\
\hline $\mathrm{x} 18$ & .117 & .704 & .096 \\
\hline $\mathrm{x} 19$ & .144 & .287 & .860 \\
\hline $\mathrm{x} 20$ & .192 & .360 & .933 \\
\hline $\mathrm{x} 21$ & .117 & .204 & .964 \\
\hline $\mathrm{x} 22$ & .194 & .287 & .660 \\
\hline $\mathrm{x} 23$ & .229 & .360 & .733 \\
\hline
\end{tabular}

After analyzing 23 variables of $\mathrm{PBB}, 3$ factors were recognized as the main factors; policymaking, implementing, and monitoring where their variables are as follows,

\section{Table 4}

The results of KMO and Bartlett tests

\begin{tabular}{lll}
\hline Kaiser-Meyer-Olkin Measure of Sampling Adequacy. & .863 \\
Bartlett's Test of Sphericity & Approx. Chi-Square & $1.210 \mathrm{E} 3$ \\
& df & 6 \\
& Sig. & .000 \\
\hline
\end{tabular}

\subsection{Variables of Policymaking Factor}

$X_{1}$.Considering the Iran's twenty-year mission (2025)

$X_{2}$.Considering the law of economic, social and cultural development (every 5 years)

$X_{3}$.Considering the law of privatization (44th principal of constitution in Iran)

$X_{4}$.Reforming annual budget law (based on PBB)

$X_{5} \cdot$ Reforming public audit law (in government)

$X_{6}$. Reforming country services management law

$X_{7}$.Creating an independent organization for advice other agencies and organizations in related to determination of outputs, outcomes and performance indexes

$X_{8}$. Creating governmental accounting standards in Iran

$X_{9}$.Implementing Accrual accounting in public segment 
$X_{10}$.Creating comprehensive management and accounting databases in agenesis

$X_{11}$.Reducing reliance on foreign loans by government

$X_{12}$. Strengthening culture of accountability in organizations and society

\subsection{Variables of Implementing Factor}

$X_{13}$.Training specialists in PBB field

$X_{14}$.Implementing the activity Based Costing

$X_{15}$.Appropriating reward and punishment system

$X_{16}$.Granting authority to managers to develop processes and administrative reform, fiscal and employment

$X_{17}$ Choosing one or more organizations as pilot before implementing PBB in all organizations

$X_{18}$.Quantifying Strategic plans accurately and implement them with precision in a current conditions and needs of citizens

\subsection{Monitoring factors}

$X_{19}$. Implementing Performance Auditing in public section

$X_{20}$.Considering financial and non-financial performance information for assessing

$X_{21}$.Considering performance information as main basis in allocating resources

$X_{22}$.Controlling the Progress of projects in public sector

$X_{23}$.Rewarding managers based on their performance

\section{Conclusion}

Performance-based budgeting depends on performance information concerning the achievement of intended organizational or program results. The introduction of performance budgeting has been linked to broader efforts to improve expenditure control as well as public sector efficiency and performance. Thus, performance budgeting can be combined with increased flexibility for managers in return for stronger accountability for the results, so as to enable them to decide how to best deliver public services. we identified all variables which are necessary for a suitable budgeting model, then the necessity of these variables in Iran was tested by the PBB experts and finally their existence have been proved by the statistical methods with the Iranian model. The article identified the necessary variables (23 variables) to establish PBB in Iran and for classifying the variables, we applied the Factor Analysis and the final derived factors are policymaking, implementing, and monitoring. Using PBB in Iran will help to better managing of resources and adding economy, efficiency and effectiveness to the process of budgeting. In fact if the budgeting system is changed then budget priorities such as controlling expenditure and improving allocation and efficient use of funds; improving public sector performance; and improving accountability to the public will be occur.

\section{References}

Blöndal, J.R., \& Kim, S.I. (2006). Budgeting in Thailand. OECD Journal on Budgeting, 5(3), 7-38. Blöndal, J.R., Kristensen, J.K., \& Ruffner, M. (2003). Budgeting in Finland. OECD Journal on Budgeting, 2(2), 119-155.

Blöndal, J.R. (2006). Budgeting in Singapore. OECD Journal on Budgeting, 6(1), 46-85. 
Blöndal, J.R., \& Ruffner, M. (2004). Budgeting in Denmark. OECD Journal on Budgeting, 4(1), 5079.

Blöndal, J. R., \& Bergvall, D. (2007). Performance budgeting in Australia. OECD Journal on Budgeting, 7(3), 1-16.

Hawkesworth, I., von Trapp, L., \& and Fjord Nielsen, D. (2011). Performance budgeting in Poland: An OECD review. OECD Journal on Budgeting, 1, 7-58.

Warren, K., \& Barnes, C. (2002). The Impact of GAAP on Fiscal Decision Making: A Review of Twelve Years' Experience with Accrual and Output-based Budgets in New Zealand. GECD Journal of Budgeting, 3(4), 8-40.

Kraan, D.J., Kostyleva, V., Forthun, C., Albrecht, J., \& Olofsson, R. (2010). Budgeting in Moldova. OECD Journal on Budgeting, 3, 1-53.

Kraan, D.J., Bergvall, D., Müller, I., Wehner, J. (2006). Budgeting in Croatia. OECD Journal on Budgeting, 5(4), 7-62.

Kim, J.M., \& Park, N. (2007). Performance budgeting in Korea. OECD Journal on Budgeting, 7(4), $1-12$.

McGill, R. (2001). Performance budgeting. IJPSM Journal, 14(5), 376-390.

Norman, Z. (2008). Performance budgeting in the united kingdom. OECD Journal on Budgeting, $8(1), 1-16$.

Willoughby, K. G., \& Makers, J. (1998). Performance-based budgeting requirement in state governments a policy brief. Atlantes GA: Georgia state university.

Young, R. D. (2003). Performance based budget systems, Public policy and practice. OECD Journal on Budgeting, 2(2), 12-24. 